\title{
PERSEPSI PESERTA DIDIK TERHADAP PENERAPAN LMS SCHOOLOGY DALAM PEMBELAJARAN IPA
}

\author{
Sri Hastuti Virgianti Pulukadang ${ }^{1)}$; Mery Napitupulu ${ }^{2)}$; Daud K. Walanda ${ }^{3)}$; Afadil $^{4)}$ \\ ${ }^{1)}$ Pendidikan Kimia/FKIP - Universitas Tadulako, Palu; srihastutibulo@yahoo.com \\ ${ }^{2)}$ Pendidikan Kimia/FKIP - Universitas Tadulako, Palu; merytn@gmail.com \\ ${ }^{3}$ Pendidikan Kimia/FKIP - Universitas Tadulako, Palu; walanda@gmail.com \\ ${ }^{4)}$ Pendidikan Kimia/FKIP - Universitas Tadulako, Palu; sukarmanafadil@yahoo.co.id
}

\begin{abstract}
The development of science and science and technology is always followed by the development of teachers and students in the field of education. Science and technology has a great influence on life and the environment. Students' understanding of science and its ability to apply it in life. Through this principle, students not only learn to listen to the teacher's explanation, but students can find out the real way of learning. The integration of technology, in this case the Schoology learning management system (LMS), is expected to help students understand science. This study aims to determine students' perceptions of the application of LMS Schoology in the seventh grade students of SMP Gamaliel Palu. The results of quantitative descriptive analysis showed that students gave a positive response to the progress of science by using Schoology.
\end{abstract}

Keywords: Natural scienc learning; perception; learning management; system; schoology

\begin{abstract}
ABSTRAK
Perkembangan ilmu pengetahuan dan IPTEK selalu diikuti dengan perkembangan guru dan peserta didik di bidang pendidikan. IPTEK memiliki pengaruh yang besar terhadap kehidupan dan lingkungan. Pemahaman peserta didik terhadap sains dan kemampuannya mengaplikasikannya dalam kehidupan. Melalui asas ini, peserta didik tidak hanya belajar mendengarkan penjelasan guru, tetapi peserta didik dapat mengetahui cara pembelajaran yang sebenarnya. Pengintegrasian teknologi dalam hal ini learning management system (LMS) Schoology diharapkan dapat membantu pemahaman peserta didik terhadap sains. Penelitian ini bertujuan untuk mengetahui persepsi peserta didik terhadap penerapan LMS Schoology dalam pembelajaran IPA peserta didik kelas VII SMP Gamaliel Palu. Hasil analisis deskriptif kuantitatif diketahui bahwa peserta didik memberikan respon positif terhadap kiprah sains dengan menggunakan Schoology.
\end{abstract}

Kata kunci: Pembelajaran IPA; Persepsi; Manajemen Pembelajaran; Sistem; Schoology

\section{PENDAHULUAN}

Perkembangan ilmu pengetahuan dalam bidang teknologi dan informasi saat ini merambah ke berbagai sektor kehidupan utamanya sektor pendidikan. Keberadaannya membawa perubahan sebagai tool dalam pembelajaran.
Pemanfaatannya sangat penting karena memberikan kesempatan bagi peserta didik untuk belajar dan menerapkan keterampilannya. Selain itu, guru dapat menyajikan pembelajaran yang lebih menarik (Ratheeswari, 2018). Untuk itu, pengaplikasian teknologi dan informasi 
memastikan efisiensi proses pembelajaran (Dikova dkk., 2019) Salah satu upaya untuk meningkatkan efisiensi pembelajaran adalah melalui integrasi teknologi dengan proses pembelajaran (Wahyuni, 2017). Dalam beberapa tahun terakhir, teknologi mulai beralih fungsi dari alat bantu pembelajaran menjadi kebutuhan dasar pendidikan. Oleh karenanya, lebih dari tujuh juta pengguna merupakan pesrta didik SMP dan SMA (Sarrab dkk., 2016).

Pembelajaran dapat berlangsung di mana dan kapan saja. Antara guru dan peserta didik dapat melangsungkan proses belajar mengajar selain di dalam kelas. Peserta didik mengaplikasikan keterampilan berpikir, keterampilan informasi dan komunikasi, serta literasi ilmiah menggunakan teknologi digital (Cavus \& Alhih, 2014).

Berbagai teknologi baru dapat digunakan dan salah satunya adalah learning management system (LMS). Teknologi ini sedang berkembang dan membawa perubahan. Oleh sebab itu, guru dan peserta didik ataupun para praktisi pendidikan seharusnya memiliki pengetahuan tentang LMS Schoology sehingga dapat menggunakannya (Cavus, 2015). Dengan mengaplikasikan LMS, maka dapat mengefektifkan delivery instruction antara guru dan peserta didik. Akses terhadap LMS pun dapat didasarkan pada kemudahan dalam mengakses materi pembelajaran yang dapat dilakukan kapanpun dan dimanapun (Black dkk., 2007).

Salah satu LMS yang tersedia secara gratis dan mudah untuk digunakan adalah Schoology. Menu-menu dalam Schoology membantu para penggunanya menghadapi kemajuan teknologi dan informasi serta kebutuhan pembelajar modern (Sicat, 2015). Aplikasi ini berfungsi untuk mempermudah komunikasi antara guru dan pesrta didik. Orang tua pun dapat ambil bagian dalam aplikasi ini, sehingga akan lebih mudah untuk mengontrol perkembangan anaknya. Sebagai alat manajemen pembelajaran, memungkinkan guru untuk menyediakan bahan ajar, mengatur, dan mengevaluasi pembelajaran. Rosalina (2018) menunjukan integrasi Schoology dalam pembelajaran IPA dapat meningkatkan motivasi peserta didik karena mudah digunakan dan mengubah cara penyelesaian tugas. Peserta didik juga merasa lebih senang pada saat belajar menggunakan Schoology.

Berdasarkan latar belakang di atas dan didukung oleh tawaran penelitian, maka penelitian ini diharapkan dapat memberikan informasi baru tentang pembelajaran literasi saintifik melalui penerapan LMS Schoology. Oleh sebab itu, penelitian ini akan dilaksanakan di SMP Gamaliel Palu, sebagai bahan pertimbangan : 1. Guru dan peserta didik di SMP Gamaliel Palu belum memahami tentang adanya LMS Schoology yang dapat 
dimanfaatkan kegunaanya secara online. 2. Proses pembelajaran peserta didik SMP Gamaliel Palu masih terbatas dengan tatap muka di dalam kelas. 3. Guru dan Pesrta didik di SMP Gamaliel telah memiliki infrasktruktur internet dan laptop ataupun komputer yang sudah memadai.

\section{METODE PENELITIAN}

Penelitian ini menggunakan pendekatan kuantitatif-deskriptif untuk melihat persepsi pesrta didik terhadap penerapan LMS Schoology pada pembelajaran IPA pesrta didik kelas VII SMP Gamaliel palu. Respon angket persepsi akan diidentifikasi menggunakan 4 poin Skala Likert, diantaranya 4 (sangat setuju), 3 (setuju), 2 (kurang setuju), dan 1 (sangat tidak setuju).

Populasi dalam penelitian ini adalah seluruh pesrta didik kelas VII SMP Gamaliel Palu. Sampel merupakan bagian dari jumlah dan karakteristik yang dimiliki oleh populasi. Pengambilan sampel menggunakan teknik purposive sampling yaitu teknik pengambilan sampel dengan pertimbangan tertentu (Sugiyono, 2013).
Sehingga sampel pada penelitian ini kelas VII Korintus SMP Gamaliel Palu.

Variabel dalam penelitian ini adalah melihat persepsi pesrta didik terhadap pengaruh penerapan LMS Schoology pada pembelajaran IPA peserta didik kelas VIII SMP Gamaliel Palu dan dilaksanakan di SMP Gamaliel Palu pada bulan Agustus September.

\section{HASIL DAN PEMBAHASAN}

Pada dasarnya LMS seperti Schoology meningkatkan perhatian peserta didik dengan penambahan teknologi berbasis WEB ke dalam proses pengajaran dan pembelajaran. Teknologi ini menciptakan peluang baru untuk berinteraksi dengan teman sebaya, guru, serta bahan ajar. Dimana penelitian ini menunjukan bagaimana persepsi peserta didik terhadap pembelajaran dengan menggunakan LMS Schoology. Persepsi peserta didik dilihat dari 5 kriteria, yang dijabarkan pada tabel $1 \mathrm{~s} / \mathrm{d}$ tabel 5:

Tabel 1. Mudah digunakan

\begin{tabular}{|c|c|l|c|c|}
\hline No & Kriteria & \multicolumn{1}{|c|}{ ITEM } & Mean (M) & $\begin{array}{c}\text { Standar Deviasi } \\
\text { (SD) }\end{array}$ \\
\hline 1 & & $\begin{array}{l}\text { Saya menemukan sistem LMS Schoology } \\
\text { mudah digunakan pada saat ini }\end{array}$ & 3,39 & 0,832 \\
\hline 2 & $\begin{array}{l}\text { Saya menemukan sistem LMS Schoology juga } \\
\text { mudah digunakan dalam pembelajaran IPA } \\
\text { pada saat ini }\end{array}$ & 3,25 & 0,701 \\
\hline 3 & $\begin{array}{l}\text { Sangat mudah untuk menjadi terampil dalam } \\
\text { menggunakan LMS Schoology dalam } \\
\text { pembelajaran IPA }\end{array}$ & 2,86 & 0,756 \\
\hline
\end{tabular}


Tabel 2. Manfaat yang dirasakan

\begin{tabular}{|l|l|l|c|c|}
\hline No & Kriteria & \multicolumn{1}{|c|}{ Item } & Mean (M) & $\begin{array}{c}\text { Standar Deviasi } \\
\text { (SD) }\end{array}$ \\
\hline 1 & & $\begin{array}{l}\text { LMS Schoology akan meningkatkan kinerja } \\
\text { saya dalam belajar IPA }\end{array}$ & 2,93 & 0,979 \\
\hline 2 & $\begin{array}{l}\text { LMS Schoology akan meningkatkan } \\
\text { produktivitas dan kreatifitas saya dalam belajar } \\
\text { IPA }\end{array}$ & 2,89 & 0,916 \\
\hline 3 & $\begin{array}{l}\text { LMS Schoology membantu saya lebih mudah } \\
\text { memepelajari konten pelajaran IPA }\end{array}$ & 3,32 & 0,863 \\
\hline 4 & $\begin{array}{l}\text { LMS Schoology mendukung simbol-simbol } \\
\text { yang digunakan dalam pembelajaran IPA }\end{array}$ & 3,50 & 0,923 \\
\hline 5 & $\begin{array}{l}\text { LMS Schoology memudahkn pesrta didik dan } \\
\text { guru berkomunikasi }\end{array}$ & 2,93 & 1,184 \\
\hline 6 & $\begin{array}{l}\text { LMS Schoology mendukung proses } \\
\text { pengidentifikasian masalah, pemecahan } \\
\text { masalah, pengambilan keputusan berdasarkan } \\
\text { fakta, serta pemberian kesimpulan pada } \\
\text { pembelajaran }\end{array}$ & 3,21 & 0,833 \\
\hline 7 & $\begin{array}{l}\text { LMS Schoology membantu saya dalam } \\
\text { mendownload dan mengupload file dalam } \\
\text { bentuk tugas ataupun video pembelajaran }\end{array}$ & 3,21 & 0,101 \\
\hline 8 & $\begin{array}{l}\text { LMS Schoology membantu saya dalam } \\
\text { mengatur kecepatan saya dalam bealajar IPA }\end{array}$ & 2,96 & 0,962 \\
\hline
\end{tabular}

Tabel 3. Sikap peserta didik

\begin{tabular}{|c|c|l|c|c|}
\hline No & Kriteria & \multicolumn{1}{|c|}{ ITEM } & Mean (M) & $\begin{array}{c}\text { Standar Deviasi } \\
\text { (SD) }\end{array}$ \\
\hline 1 & & $\begin{array}{l}\text { Belajar melalui LMS Schoology adalah ide } \\
\text { yag baik dalam pembelajaran IPA }\end{array}$ & 3,39 & 0,832 \\
\hline 2 & $\begin{array}{l}\text { Saya memiliki pandangan positif terhadap } \\
\text { LMS Shoology yang digunakan dalam } \\
\text { pembelajaran IPA }\end{array}$ & 3,25 & 0,701 \\
\hline
\end{tabular}

Tabel 4. Sistem aksesbilitas

\begin{tabular}{|c|c|l|c|c|}
\hline No & Kriteria & \multicolumn{1}{|c|}{ ITEM Mean (M) } & $\begin{array}{c}\text { Standar Deviasi } \\
\text { (SD) }\end{array}$ \\
\hline 1 & & $\begin{array}{l}\text { Saya tidak mengalami kesulitan dalam } \\
\text { mengaksesdan menggunakan LMS Schoology }\end{array}$ & 2,57 & 1,200 \\
\hline 2 & $\begin{array}{l}\text { Saya dapat mengakses pembelajaran IPA } \\
\text { melalui Schoology dimanapun dan kapanpun }\end{array}$ & 3,36 & 0,989 \\
\hline 3 & $\begin{array}{l}\text { Secara keseluruhan LMS Schoology adalah } \\
\text { membantu proses pembelajaran IPA }\end{array}$ & 3,32 & 0,905 \\
\hline
\end{tabular}

Tabel 5. Niat perilaku

\begin{tabular}{|c|c|l|c|c|}
\hline No & Kriteria & \multicolumn{1}{|c|}{ ITEM } & Mean (M) & $\begin{array}{c}\text { Standar Deviasi } \\
\text { (SD) }\end{array}$ \\
\hline 1 & & $\begin{array}{l}\text { Saya berniat menggunakan LMS Schoology } \\
\text { dalam pembelajaran IPA secara terus-menerus }\end{array}$ & 2,43 & 1,069 \\
\hline 2 & $\begin{array}{l}\text { Saya berniat mencek informasi di LMS } \\
\text { Schoology }\end{array}$ & 2,79 & 0,833 \\
\hline
\end{tabular}




\section{Mudah digunakan}

Tabel 1 memperlihatkan hasil analisis kemudahan untuk menggunakan LMS Schoology. Para peserta didik berpendapat bahwa LMS Schoology mudah digunakan di era pembelajaran digital saat ini. Dengan skor $\mathrm{M}=3,39$ menunjukan kriteria penilaian persepsi sedang. Demikian halnya, Schoology juga mudah diaplikasikan dalam pembelajaran IPA yang di dalamnya mencangkup ilmu-ilmu abstrak, perhitungan, dan penjabaran halhal mikroskopik. Sistem yang ada memudahkan para pesrta didik untuk mengakses pelajaran IPA yang diintegrasikan kedalamnya $(M=3,25)$.

Kemudahan lainnya mengacu kepada keterampilan dalam mengelolah pembelajaran peserta didik secara mandiri. Dengan menggunakan Schoology dalam pembelajaran IPA, peserta didik diharapkan memiliki keterampilan dalam mangatur pembelajarannya. Berdasarkan tanggapan peserta didik, skor $\mathrm{M}=2,86$ dengan kriteria penilaian persepsi sedang, mengandung arti bahwa peserta didik menjadi sangat mudah untuk menjadi terampil menggunakan LMS Schoology dalam pembelajaran IPA. Pesrta didik dapat mengatur bahan bacaan, tugas, menonton video yang disubmit oleh guru dengan lebih terarah. Sehingga peserta didik tidak berpikir secara acak-acakan dalam mempersiapkan proses belajarnya.

\section{Manfaat yang dirasakan}

Manfaat menggunakan Schoology merupakan pengaruh yang dirasakan oleh peserta didik. Bagaimana Schoology lebih memberikan manfaat dalam pembelajaran peserta didik. Tabel 3 menjelaskan manfaat-manfaat apa saja yang dirasakan oleh peserta didik pada saat pengaplikasian Schoology dalam pembelajaran. Dengan adanya Schoology, peserta didik terbantukan dalam hal meningkatkan kinerja $(\mathrm{M}=2,93)$ dan produktivitas serta kreatifitas $(\mathrm{M}=2,89)$ dalam pembelajaran IPA. Konten-konten yang diciptakan oleh guru dalam Schoology mudah dipelajari oleh peserta didik $(\mathrm{M}=3,32)$.

Selanjutnya, perlu diketahui bahwa dalam pembelajaran IPA terdapat simbolsimbol. Guru dan peserta didik akan merasa sulit jika alat yang digunakan tidak dapat menunjang konten tersebut. Menggunakan Schoology, penulisan simbol-simbol yang berkaitan dengan pembelajaran IPA juga dapat dilakukan tanpa harus meninggalkan platform Schoology $(\mathrm{M}=3,50)$.

Manfaat lainnya yang dirasakan oleh peserta didik adalah terjalinnya komunikasi tanpa harus bertatap muka. Schoology memudahkan guru dan peserta didik untuk saling berkomunikasi $(\mathrm{M}=$ 2,93). Selain itu, dalam pembelajaran IPA juga mengandung tahap-tahap pengidentifikasian masalah, pengambilan keputusan dengan melihat fakta, serta 
memberikan kesimpulan dalam pembelajaran. Hal-hal tersebut juga dapat dilakukan dengan menggunakan Schoology $(\mathrm{M}=3,21)$. Kegiatan tersebut akan dilanjutkan dengan mengumpulkan kembali kepada guru. Schoology berperan dalam membantu peserta didik untuk mensubmit tugas ataupun video pembelajaran tanpa harus bertemu secara langsung dengan guru $(\mathrm{M}=3,21)$. Sehingga, kondisi ini juga mempengaruhi pesrta didik untuk dapat mengatur gaya belajar masing-masing peserta $\operatorname{didik}(\mathrm{M}=$ $2,96)$.

\section{Sikap peserta didik}

Saat peserta didik merasa puas dengan pembelajaran Schoology, peserta didik menunjukan sikap ketertarikan dalam pembelajaran tersebut. Belajar dengan mengintegrasikan pembelajaran ke dalam Schoology menurut peserta didik (Tabel 3) adalah ide yang baik $(\mathrm{M}=3,39)$. Peserta didik memandang positif terhadap pengaplikasian Schoology dalam pembelajaran IPA $(M=3,25)$.

\section{Sistem aksesibilitas}

Dalam hal aksesibilitas,(Tabel 4) peserta didik tidak mengalami kesulitan belajar saat menggunakan Schoology $(\mathrm{M}=$ 2,57). Mereka dapat mengakses bahan ajar, tugas, mengecek pengumuman dan video pembelajaran ataupun dalam bentuk URL. Peserta didik juga dapat mengakses pembelajaran IPA melalui LMS Schoology dimanapun dan kapanpun, hal ini menunjukan fleksibilitas Schoology $(\mathrm{M}=$ 3,36). Dimana, secara keseluruhan Schoology membantu proses pembelajaran dan pengajaran ( $\mathrm{M}=3,32)$.

\section{Niat perilaku}

Niat perilaku peserta didik tergambarkan selama proses pembelajaran berlangsung. Berdasarkan tanggapan peserta didik (Tabel 5) yang dikumpulkan menggunakan kuisioner, peserta didik berniat untuk menggunakan Schoology secara terus-menerus dalam pembelajaran IPA $(\mathrm{M}=2,43)$. Sehingga, dengan menggunakan Schoology, maka informasi yang diberikan oleh guru akan selalu dicek oleh pesrta didik $(M=2,79)$. Hal senada diungkapkan oleh Cavus \& Alhih, (2014) bahwa LMS dapat digunakan meningkatkan sistem pendidikan di sekolah.

\section{SIMPULAN DAN SARAN SIMPULAN}

Peserta didik memberikan tanggapan positif terhadap penggunaan LMS Schoology dalam pembelajaran IPA. Peserta didik mendapatkan pengalaman baru ditinjau dari kemudahannya, manfaat yang diperoleh, sikap peserta didik, aksesibilitas serta niat dan perilaku peserta didik.

\section{SARAN}

LMS Schoology dapat digunakan untuk meningkatkan sistem managemen disekolah. 


\section{UCAPAN TERIMA KASIH}

Penulis mengucapkan terima kasih kepada seluruh pihak yang telah membantu dalam penelitian ini,sehingga penelitian ini berjalan dengan baik.

\section{DAFTAR PUSTAKA}

Black, E. W., Beck, D., Dawson, K., Jinks, S., \& Dipietro, M. (2007). The other side of the LMS: considering implementation and use in the adoption of an LMS in online and blended learning environments. Jurnal Pendidikan IPA, 51(2), 35-39;

Cavus, N. (2015). Distance learning and learning management systems. Procedia - Social and Behavioral Sciences, 191, 872-877;

Cavus, N., \& Alhih, M. S. (2014). Learning management systems use in science education. Procedia - Social and Behavioral Sciences, 143, 517520;

Dikova, T. V., Kovaleva, T. A., Smirnova, E. A., Aleevskaya, Y. I., \& Oreshin, D. N. (2019). Effective communication technologies. International Journal of Advanced Trends in Computer Science and
Engineering, 8(6), 3282-3288;

Ratheeswari, K. (2018). Information communication technology in education. Journal of Applied and Advanced Research, 3(S1), 45;

Rosalina, M. (2018). Analysis the use of schoology e-learning towards students' learning motivation enhancement in STKIP Surya. Indonesian Journal of Science and Education, 2(1), 89;

Sarrab, M., Elbasir, M., \& Alnaeli, S. (2016). Computers in human behavior towards a quality model of technical aspects for mobile learning services: an empirical investigation. 55, 100102 ;

Sicat, A. S. (2015). Enhancing college students' proficiency in business writing via schoology. International Journal of Education and Research, 3(1), 159-178;

Sugiyono. (2013). Metode Penelitian Pendidikan. Bandung: Alfabeta;

Wahyuni, S. (2017). Design and implementation of schoology-based blended. Jurnal Pendidikan IPA, 6(1), 170-178. 